InOedia $\quad \begin{aligned} & \text { InMedia } \\ & \text { The French Journal of Media Studies }\end{aligned}$

3 | 2013

Cinema and Marketing

\title{
Judith Brodie (ed.), Shock of the News
}

Washington, D.C.: National Gallery of Art, 2012, 154 pages

Jason E. Hill

\section{(2) OpenEdition}

\section{Journals}

Electronic version

URL: http://journals.openedition.org/inmedia/570

DOI: $10.4000 /$ inmedia. 570

ISSN: 2259-4728

Publisher

Center for Research on the English-Speaking World (CREW)

Electronic reference

Jason E. Hill, « Judith Brodie (ed.), Shock of the News », InMedia [Online], 3 | 2013, Online since 15 April 2013, connection on 24 September 2020. URL : http://journals.openedition.org/inmedia/570 ; DOI : https://doi.org/10.4000/inmedia.570

This text was automatically generated on 24 September 2020.

(C) InMedia 


\section{Judith Brodie (ed.), Shock of the News}

Washington, D.C.: National Gallery of Art, 2012, 154 pages

Jason E. Hill

REFERENCES

Judith Brodie (ed.), Shock of the News, Washington, D.C.: National Gallery of Art, 2012, 154 pages 
1 With shifting emphases and varying degrees of success, a spate of recent exhibitions-most notably Warhol: Headlines at the National Gallery of Art, Washington, D.C. in 2012, The Last Newspaper at the New Museum in 2010, Antiphotojournalism at La Virreina in 2010, and Covering the Real at the Kunstmuseum Basel in 2005-have taken on the question of the visual arts' engagement with the material, culture, and procedures of journalism. But for all these exhibitions' considerable merit in advancing an analysis of journalism through the optic of the art world's substantial theoretical

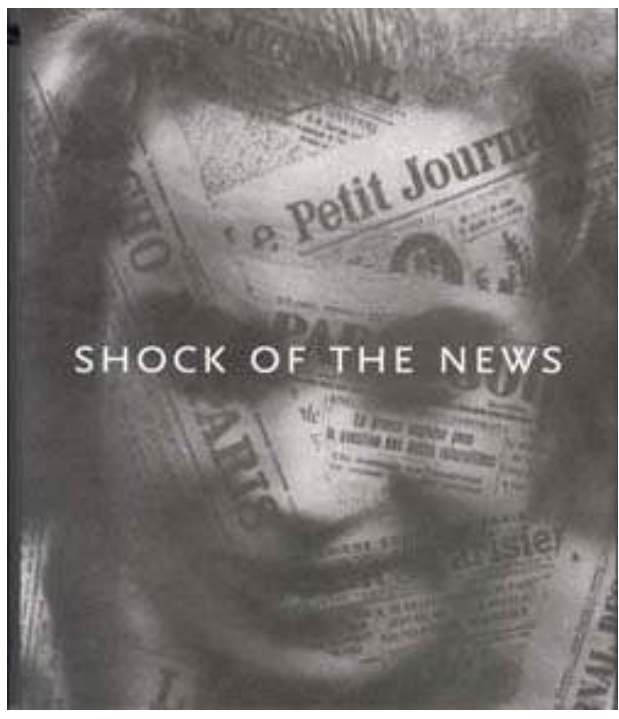
and formal critical competence, they have limited their inquiry into the art/journalism nexus to the "contemporary" or post-1960 period. To some extent, this historical framework makes sense. The conditions of both art and journalism have changed in a number of meaningful ways since 1960, lending a certain comfort to their unlikely exhibitionary convergence; changes in terms of both the variety of media employed by each and of their relationship with their publics. But the artistic and art critical encounter with the world of journalism has much deeper historical roots, and Judith Brodie's 2012 exhibition Shock of the News offers a welcome corrective to this curatorial over-privileging of the contemporary, by demonstrating the centrality of that engagement to canonical modernism in the visual arts since 1909 and the coherence of its steady development since.

2 This broader historical scope appears to have necessitated a narrower conceptual frame, however. Unlike the organizers of these previous exhibitions, Brodie and her collaborating essayists-Sarah Boxer, Janine Mileaf and Matthew Witkovksy, and Christine Poggi-are concerned less with art in its involvement with journalism as a social field (such as we find in a work like David Lamelas' 1968 Office of Information about the Vietnam War at Three Levels: The Visual Image, Text, and Audio, where "news" is understood as a complex human, material, and technological network) than they are with artists' use of the newspaper itself as a subject and to a greater degree as a material. (To call it a medium here would only confuse matters : three of four essays cite Greenberg ; not one mentions McLuhan.)

With this unstated rubric in place, Brodie advances a sort of origin myth of modernism's fascination with "the newspaper phenomenon," positing the appearance of Marinetti's Futurist manifesto on the cover of Le Figaro in 1909 and Pablo Picasso's 1912 papier collé Guitar, Sheet Music, and Glass (the first artwork to be "self-consciously modern" in its incorporation of a bit of newspaper) as two distinct but approximately contemporary points of genesis. The two occasionally braiding trajectories sprung from these are elaborated most efficiently (if tentatively) by Witkovsky and Mileaf: "The paired legacy of Picasso and Marinetti, as explored in this book, suggests a dual mode of interaction with the daily papers. On one hand are works [like Picasso's] that deal with the fragmentary everydayness of modern life through the material of newsprint itself ; on the other are those [like Marinetti] that mimic or infiltrate the apparatus of 
newspaper publishing and its increasingly commodified public." (104) Despite frequent reference to John Heartfield, who did not only "infiltrate" but actually productively worked for the press, Shock of the News is concerned almost exclusively with the former, "material" orientation, and essays return again and again, with an almost dogged persistence, to the analysis of the newspaper collages of Picasso, Braque, and Hoch and the newspaper paintings of Rauschenberg, Johns, Robert Morris, and Warhol ; the five authors contribute four more or less interchangeable readings of Dieter Roth's Literaturwurst series (1961), which literally makes a sausage of the newspaper and which survives the repetition on its own merit.

4 For all of the assembled authors, each an accomplished historian or curator of the modernist avant-garde, what unifies these two divergent trajectories is an artistic preoccupation not with the newspaper's quality as the material accretion of a global journalistic network or as a conduit for information about social injustice (or sports scores, or what have you), but with the distinctive and symptomatically modern temporality and fragmentation contained in its form. If the approach to the medium is often Greenbergian, the modernity here is that of Benjamin and Mallarmé. Of news time Witkovsky and Mileaf note, with characterist élan : "Yellowing almost before one's eyes, newsprint carries a material currency only slightly greater than its validity as a bearer of fresh information" (103). Sarah Boxer writes beautifully and with erudition. A former New York Times art critic, she knows something about newspapers. Here she at once describes and performs the newspaper's fragmentary condition, suggesting something of the appeal it held for a Picasso or Carlo Carrà :

It is the clash of headlines and ads, news and weather. The optical buzz of the set type... It is the size of the page, the crinkle of the sheets, then ink on your fingers. The types of type. The datelines and bylines. And the blunt lingo of the newsroom and the composing room. The hed. The lede. Kerning and carding. $\mathrm{H} \& \mathrm{~J}$. TKTKTKTK. Agate type. Dummy type. Thumbsucker. Q-hed. The news hole. The nut-graf. The banner. The kicker. The jump. The slug. The slot. The widows and orphans. The morgue. (91)

5 This is the quick clip and staccato rhythm that the newspaper always already has and that modern art desires. In the interaction of modernism and the newspaper where the modernist is always taking the knife to the newspaper, Boxer observes rivalry driven by envy: "When I see art incorporating newspapers," Boxer writes, warning that she might be overly protective of the newspaper, having worked for one, "I see a war against the once-composed page. I see the newspaper tortured: cut, gutted, minced, diced, snuffed, silenced, defiled, mocked, tarred, drowned, bound, gagged." (92)

Boxer's essay notwithstanding, it is possible to detect a gentler or at least more passive version of that same hostility to the newspaper in the catalogue (and thus the exhibition) as a whole. With the predictable exception of Heartfield, whose avant-garde credentials were secured long ago, and Semen Fridlian, whose The Venal Press (where hostility to the press speaks for itself) enjoys pride of place on the catalogue's cover, but which is uncharacteristic for this inventive Soviet photojournalist in its montaged and therefore recognizably avant-garde aspect, I searched in vain for mention of Winsor McCay, John Sloan, Weegee, Ad Reinhardt, Taryn Simon, Cartier-Bresson or any museum-sanctioned artist who had actually produced important art in the service of newspaper journalism. El Lissitzky's and Sergei Sen'kin's Presse catalogue is frequently cited, but this of course is in connection with an exhibition about newspapers, not anything that was happening inside them. Louis Aragon is mentioned twice, but as a 
deft analyst of dada collage and not for his work publishing the interwar Parisian daily Ce Soir. Lyonel Feininger is the first artist mentioned, in the Director's forward, but in light of his 1909 painting Newspaper Readers and not as any tribute to his astonishingly inventive 1906 Kin-der-Kids comics for the Chicago Tribune. Warhol enjoys frequent discussion, but for his later art about newspapers and not for the extraordinary drawings for I. Miller that were published as advertisements in newspapers. Boxer does mention that Mallarmé, a theoretical lynchpin of the proceedings, wrote criticism for the dailies, but his role here is anything but the ombudsman's. Rather, his familiar protestations against the newspaper echo from some space well outside newsprint. Tellingly, the only other newspaper staffer to appear in the index is George Luks, an artist of unassailable modernity, but who appears only as the rearguard butt of the vanguard Arthur Dove's Dadaist newspaper-collage ridicule.

How do we account for this evasion-in a book about modernism's traffic with the newspaper-of the cartoonists and the artist-reporters, those modern artists who made their modern art (and quickly!) for presentation in that most modern material form ? Shock of the News, unfortunately, does not offer any explanation, or any sustained accounting for the structuring limit dividing its modernism from its journalism. My sense is that it would be rather difficult in the end to formulate a comprehensive theory holding the two fields of practice safely at bay (certainly the commodification argument doesn't hold any water). To trouble with such limit cases would be to expose cracks in the binary that is Shock of the News's very foundation. Amidst Christine Poggi's virtuoso treatment of a series of works by Ellsworth Kelly, Kelly is said to have turned in his art to newspapers as "an'outdoor source' par excellence" (118). This is a telling observation in its plain declaration of the artist's need for the newspaper to be something other than art. By the newspaper's being "outside," art is able to understand its own position as "inside." The newspaper, for all its exciting modernity, is allowed to be like a tree or a sunset, just there, an "outside," natural thing for art to be about. The polarity allows for the production of much needed walls, lest the floor of this discourse get too muddy. But then again, Kelly's newspaper works are great, so why complain?

Poggi's essay, the last in the volume and excellent on its own terms, unfortunately does not unpack the implications of all this. But she does shake things up some with brief and sharp treatments of surprising and welcome interventions by Chryssa, Arman, Carolee Schneemann, and, most interestingly, Laurie Anderson. Anderson's New York Times, Horizontal/China Times, Vertical (1971/1976) literally weaves the front pages of these spatially, temporally, and politically remote newspapers into a richly evocative field, charged with reference to, as Poggi has it, "newspaper's mobile, heterogeneous, and intertextual status within a global communications network" (126-7). This is a field of reference that has been sorely missing from this catalogue's excessively insular, material fixation on the newspaper as a fixed and coherent (even if in its fragmentation and evanescence) field of cultural meaning. The very success of Anderson's work and the privilege it enjoys in the book's design as a frontis to Poggi's essay speaks eloquently to concerns raised above. Anderson's work sparks visibility to the newspaper's condition as anything but a found thing, anything but mere inert "material" to be activated by the artist in his studio. The newspaper, this work (by Poggi's light) insists, is a dynamic and made thing, a woven thing, and it is the business of this making, the art of it-the very procedures of news work, with its wire services, tight deadlines, picture-editors, hypocrisies, foreign bureaus, rolling presses, 
contradictions, and globe-trotting photographers and reporters-that most denotes the phenomenon's profound modernity, if not its modernism.

For all of Shock of the News' considerable beauty as a book and value as a compendium tracing this unmistakably vital tendency within canonical modernism, it is this overall indifference to the complexity of actual newspaper journalism that most limits its analysis and which will stand out most markedly in the minds of readers coming to it from anywhere "outside" of art history. The volume is the publication of an art museum and naturally enough it consists of essays by two art museum curators, an art critic, an academic art historian, and an art museum director. But in a book taking stock of the "shocking" convergence of the fine arts and print journalism, it might have been productively destabilizing to have included a voice more representative of, or authoritative on, the subject of that dualism's latter term. Witkovsky and Mileaf, to their and to this volume's credit, do marshal the authority of journalism historians Kevin Barnhurst and John Nerone's excellent book The Form of the News, but only in passing and only in support of an assertion about "monolithic" print journalism's instrumentalizing lack of authorial complexity. Barnhurst, Nerone, and indeed any number of other scholars working on the visual culture of journalism from a mediastudies and communications perspective (Will Straw, Barbie Zelizer, and Thierry Gervais come quickly to mind) might have introduced a refreshing counter-discursive note, attending to the remarkable heterogeneity, complexity, and formal innovation internal to daily newspapers' own emphatically modern art history.

\section{AUTHORS}

JASON E. HILL

Terra Foundation / Institut National d'Histoire de l'Art 